\title{
Critical caveats in using product information/pregnancy categories for pregnant or breastfeeding patients
}

\author{
Majella Hill
}

\section{Background \\ Many healthcare professionals (HCPs) base their advice to pregnant or breastfeeding women on Monthly Index of Medical Specialties, Medical Director or the Consumer Medicines Information, which draw from manufacturers' product information. This information does not reflect evidence-based studies, but rather is based on animal studies conducted prior to the product's approval for use in humans and is rarely updated.}

\section{Objective}

The aim of this paper is to inform HCPs of the evidence-based resources available to assist decision making when treating pregnant or breastfeeding women.

\section{Discussion}

Women often have conditions that require treatment during their pregnancies. Experience at MotherSafe indicates that women who are pregnant or breastfeeding are frequently treated with excessive caution or even refused needed treatment by doctors and pharmacists. Product information and evidence-based sources often vary greatly in their recommendations for pregnant and lactating women. By not assessing the risks and benefits for their patients, an adverse outcome for mothers and babies may well be the result - the very outcome the cautious approach of HCPs seeks to avoid.
MotherSafe, a specialist service based at the Royal Hospital for Women in Randwick, NSW, offers free counselling and advice to healthcare professionals (HCPs) and women about exposures in pregnancy and lactation. Exposures include prescription and over-the-counter medications, street drugs, infections, radiation and occupational exposures. Analysis conducted by MotherSafe of more than 107,500 requests for advice over the five-year period 2013-17 indicates that many HCPs believe that the Therapeutic Goods Administration's (TGA's) pregnancy categories are an absolute requirement for drug use. This approach may cause considerable harm by withholding or advising against necessary medications, without considering the risks to the mother, pregnancy or fetus/breastfed child caused by the untreated medical condition. In extreme cases, MotherSafe has recorded instances in which women have been advised to terminate their pregnancies because of medication they had taken before realising they were pregnant, even though the medication was non-teratogenic. Others have been refused prescriptions for antidepressant medications or had pharmacists refuse to dispense prescriptions that were Category $\mathrm{C}$ or D on the basis that such medications would cause harm to the fetus. This is despite the Therapeutic Guidelines recommendation that 'untreated maternal depression during pregnancy is associated with increased risk of adverse obstetric and neonatal outcomes' ${ }^{1}$

\section{Discussion}

In 2016, the Australian Medicines Handbook $(A M H),{ }^{2}$ a peer-reviewed resource, removed references to the TGA pregnancy categories for the following reasons:

- Many people assume incorrectly that the alphabetical grading indicates graded safety.

- The categories do not specify the stage at which fetal development might be affected.

- The categories may not be updated to reflect the new information about the medication information.

- The categories do not address the risks and benefits of treating or not treating the medical condition.

Another shortfall is that categories do not usually distinguish between the route of administration. ${ }^{3,4}$ Drugs that might be Category $\mathrm{D}$ or even $\mathrm{X}$ when taken systemically can be less concerning when used topically, such as in eye drops or skin treatments, because of the lower absorbed dose.

The TGA's 'Prescribing medicines in pregnancy' database ${ }^{5}$ advises that the categorisation system is not hierarchical. Additionally, the TGA states that medicines in Category D are not absolutely contraindicated and that manufacturers often place a categorisation on their products that is more restrictive than can be justified. The medicolegal defensive stance that manufacturers prefer to publish in their product information can cause HCPs to take the cautionary approach, which can be to the detriment of their pregnant or breastfeeding patients.

By comparison, the US Food and Drug Administration (FDA) has introduced a 'Pregnancy and Lactation Labeling (Drugs) Final Rule' (12/3/14). ${ }^{6}$ This has removed pregnancy categories and requires 
manufacturers to provide information on the labelling of medications that assists healthcare providers to assess the risk-benefit profile of the medication, including the underlying condition being treated, when counselling pregnant and breastfeeding women. The aim is to ensure that expectant and breastfeeding mothers are able to make informed decisions about their use of medications.

There is a lack of definitive safety advice in commonly used resources such as Medical Director, Monthly Index of Medical Specialties (MIMs) and Consumer Medicines Information (CMI), which necessarily draw their information from the manufacturers. As it is unethical to include pregnant (or breastfeeding) women in clinical trials of medications, the information reports outcomes based on animal studies prior to the drug's introduction onto the market. Rarely, if ever, are the categories changed. For example, metronidazole has been available commercially for at least 50 years without adverse outcomes for fetuses or breastfed infants, yet it is classified as B2. The MotherSafe database shows that in the 14-month period from January 2017 to March 2018, MotherSafe received 254 requests for safety advice for the use of metronidazole in pregnancy and lactation. Of these, $45 \%$ were from HCPs concerned about their ability to prescribe/dispense because of the product information and its safety category of B2. The remainder were from women who had safety concerns after reading the product information or receiving advice from their pharmacist not to breastfeed while on the medication because there was a lack of studies assessing safety or because the medication category was B2.

With disparities between the advice on management of medical conditions in pregnancy and breastfeeding in the readily available Medical Director, MIMs and $\mathrm{CMI}$ and evidence from peer-reviewed information from studies in humans, it is not surprising that $\mathrm{HCPs}$ frequently err on the side of caution. However, HCPs who view the category/product information as an absolute when giving advice may leave themselves open to complaints against them, should that advice actually cause harm to the patient or her unborn/ breastfed baby. Even when giving appropriate, evidence-based advice to their patients, HCPs should discuss the risks of the underlying condition causing harm if untreated, compared with the baseline risk in any pregnancy of having a major birth defect or miscarriage, so that their patients are able to make informed decisions. In an increasingly computer-literate society, pregnant and breastfeeding women do their own research and, frequently, will find alarming information that may cause them to choose not to treat their condition, unless the clinician has been able to reassure them with sound, evidence-based information and counselling. Table 1 shows a few examples of the variances in advice available. Pharmacists should be mindful of this variability and be able to caution their patients against outdated information and provide current evidencebased information.

Similarly, HCPs may be reluctant to give advice to breastfeeding women, with MotherSafe database files indicating that HCPS often assume that if a drug is contraindicated in pregnancy, it is also contraindicated in lactation. Again, the evidence-based resources give advice that is very different from the product information (Table 2). The safety considerations of a particular drug are often very different for breastfeeding women. Indeed, very few drugs are contraindicated in lactation. ${ }^{7}$ In this case, one needs to consider the age and health of the baby - for example, a healthy baby aged two months versus an unwell, premature neonate - as well as the pharmacokinetics of the drug. Issues that influence the amount of drug entering the baby's bloodstream via breast milk include: ${ }^{7}$

- the amount of protein binding

- the molecular weight of the drug

- the pKa

- the lipophilicity

- acid lability

- oral availability.

\section{Conclusion}

Conflicting advice causes great confusion and/or alarm for pregnant or breastfeeding women, who want the best for their babies, even at the expense of their own health. Compounding this confusion is the fact that most women are computer literate and may be exposed to conflicting advice via the internet. Should they then have an adverse outcome for their child or themselves and discover it could have been avoided by having been treated appropriately, some may well be inclined to lodge a complaint. Given that complaints to the Australian Health Practitioner Regulation Agency (AHPRA) in 2016-17 increased by $13.9 \%$, and $42.9 \%$ of the complaints were based on clinical care and $11.9 \%$ on pharmacy/medication, ${ }^{8}$ HCPs would be well advised to familiarise themselves with the evidence-based resources available, many of which have factsheets online and are freely available to all. In that way, they can ensure that they and their patients are directed to reliable, accurate information on which to base their decisions. Examples suitable for HCPs and the general public include Lactmed, Motherisk, MothertoBaby, MotherSafe and BUMPS. These resources are easily accessible on the internet.

MotherSafe receives an average of 23,000 calls per year. In 2017 , the MotherSafe database showed that $71 \%$ of callers were from consumers, the majority of whom wanted to 'double check' that the advice given by their HCP was correct. It is clear from those who access the service that the level of anxiety is very high for those treating patients and those being treated while pregnant or breastfeeding. Knowing, therefore, how to access resources that provide accurate, evidencebased information will go some way to alleviating some of that anxiety, at least for HCPs, and give them the confidence to make better informed decisions with respect to treating/dispensing, rather than taking a more simplistic, risk-averse approach, which, in some cases, may cause more harm than the medication and does not adhere to the HCP's charter to 'do no harm'.

\section{Evidence-based resources}

- Australian Medicines Handbook

- Australian immunisation handbook

- Australian Therapeutic Guidelines

- Batagol R. Taking medicines in pregnancy. Sunnybank Hills, Qld: Book Pal, 2013. 
Table 1. Examples of differing pregnancy advice between evidence-based resources and product information citing commonly queried medications received at MotherSafe

\begin{tabular}{|c|c|c|c|c|}
\hline Drug & $\begin{array}{l}\text { Australian Medicines } \\
\text { Handbook }\end{array}$ & Reproductive toxicology & $\begin{array}{l}\text { Monthly Index of Medical } \\
\text { Specialties }\end{array}$ & $\begin{array}{l}\text { Consumer Medicines } \\
\text { Information }\end{array}$ \\
\hline $\begin{array}{l}\text { Doxylamine } \\
\text { Doxylamine/ } \\
\text { pyridoxine } \\
\text { combination }\end{array}$ & $\begin{array}{l}\text { - Safe to use in pregnancy } \\
\text { - Antihistamines } \\
\text { used extensively as } \\
\text { antiemetics and to treat } \\
\text { allergies } \\
\text { - No evidence of fetal } \\
\text { adverse effects }\end{array}$ & $\begin{array}{l}\text { - No evidence from animal } \\
\text { studies and human } \\
\text { experience for increased } \\
\text { risk of congenital anomalies } \\
\text { during pregnancy }\end{array}$ & $\begin{array}{l}\text { - Category listing } \\
\text { - Do not use during pregnancy }\end{array}$ & $\begin{array}{l}\text { Do not use if pregnant } \\
\text { of intending to become } \\
\text { pregnant } \\
\text { - Safety studies in } \\
\text { pregnancy in humans } \\
\text { not available }\end{array}$ \\
\hline $\begin{array}{l}\text { Selective } \\
\text { serotonin } \\
\text { reuptake } \\
\text { inhibitors } \\
\text { (SSRIs) }\end{array}$ & $\begin{array}{l}\text { Most data indicate no } \\
\text { association with increased } \\
\text { malformations } \\
\text { - Some studies suggest an } \\
\text { increased risk (fetal heart } \\
\text { defects), particularly with } \\
\text { paroxetine } \\
\text { - Some epidemiologic data } \\
\text { suggest an association } \\
\text { between SSRIs and } \\
\text { premature delivery } \\
\text { - Neonatal toxic symptoms, } \\
\text { including persistent } \\
\text { pulmonary hypertension } \\
\text { reported, particularly with } \\
\text { paroxetine use in late } \\
\text { pregnancy } \\
\text { Self-limited withdrawal } \\
\text { effects (eg irritability } \\
\text { and altered muscle tone) } \\
\text { may occur } \\
\text { Dose increase many be } \\
\text { required in late pregnancy } \\
\text { Decreasing the dose in } \\
\text { the weeks before delivery } \\
\text { may reduce neonatal } \\
\text { withdrawal or toxic effects, } \\
\text { although supporting } \\
\text { evidence is lacking }\end{array}$ & $\begin{array}{l}\text { - Animal studies and human } \\
\text { experience indicate sertraline } \\
\text { is not expected to increase } \\
\text { the risk of congenital } \\
\text { anomalies } \\
\text { - Human studies have } \\
\text { inconsistently reported } \\
\text { associations of sertraline use } \\
\text { during pregnancy and various } \\
\text { defects in the offspring } \\
\text { - Use of SSRIs in late } \\
\text { pregnancy associated with } \\
\text { a mild transient neonatal } \\
\text { syndrome of central nervous } \\
\text { system, motor, respiratory } \\
\text { and gastrointestinal signs } \\
\text { Some studies suggest use } \\
\text { of fluoxetine, sertraline or } \\
\text { paroxetine is associated with } \\
\text { increased risk of neonatal } \\
\text { pulmonary hypertension in } \\
\text { some but not all studies } \\
\text { Long-term } \\
\text { neurodevelopmental studies } \\
\text { suggest that antenatal } \\
\text { exposure to fluoxetine, } \\
\text { sertraline or paroxetine } \\
\text { does not adversely affect } \\
\text { outcomes }\end{array}$ & $\begin{array}{l}\text { Exposure to sertraline, other SSRIs or } \\
\text { serotonin and norepinephrine reuptake } \\
\text { inhibitors (SNRIs) late in third trimester } \\
\text { associated with neonates developing } \\
\text { complications requiring prolonged } \\
\text { hospitalisation, respiratory support and } \\
\text { tube feeding } \\
\text { - Such complications can arise } \\
\text { immediately on delivery } \\
\text { - Reported clinical findings include } \\
\text { respiratory distress, cyanosis, } \\
\text { apnoea, seizures, temperature } \\
\text { instability, feeding difficulty, } \\
\text { vomiting, hypoglycaemia, hypotonia, } \\
\text { hyperreflexia, tremor, jitteriness, } \\
\text { irritability, and constant crying } \\
\text { - These features are consistent with } \\
\text { either a direct toxic effect of SSRIs } \\
\text { and SNRIs or, possibly, a drug } \\
\text { discontinuation syndrome }\end{array}$ & $\begin{array}{l}\text { Patients advised to tell } \\
\text { doctor if they become } \\
\text { pregnant while taking } \\
\text { sertraline } \\
\text { - Women of child-bearing } \\
\text { age advised to avoid } \\
\text { becoming pregnant } \\
\text { while taking sertraline } \\
\text { - Reports that babies } \\
\text { exposed to sertraline and } \\
\text { other antidepressants in } \\
\text { the third trimester may } \\
\text { develop complications } \\
\text { immediately after birth }\end{array}$ \\
\hline Aciclovir & $\begin{array}{l}\text { - Safe to use } \\
\text { - Extensive clinical } \\
\text { experience }\end{array}$ & $\begin{array}{l}\text { Animal studies and human } \\
\text { experience indicate that } \\
\text { typical doses of aciclovir } \\
\text { should not increase the risk } \\
\text { of congenital anomalies }\end{array}$ & $\begin{array}{l}\text { There are no adequate, well-controlled } \\
\text { studies on the safety of aciclovir in } \\
\text { pregnant women } \\
\text { - Should not be used during pregnancy } \\
\text { unless benefits to the patient clearly } \\
\text { outweigh the potential risks to the } \\
\text { fetus } \\
\text { - If suppressive therapy is used in } \\
\text { the perinatal period, it should not } \\
\text { be assumed that viral shedding has } \\
\text { ceased or that the risk to fetus/neonate } \\
\text { has decreased. } \\
\text { - Pregnancy should be managed } \\
\text { according to considerations normally } \\
\text { applicable to patients with genital herpes }\end{array}$ & $\begin{array}{l}\text { Patients advised to } \\
\text { tell their doctor before } \\
\text { taking aciclovir if they } \\
\text { are pregnant or if they } \\
\text { become pregnant while } \\
\text { using aciclovir }\end{array}$ \\
\hline
\end{tabular}

- Briggs GG, Freeman RK, Towers CV, Forinash AB. Drugs in pregnancy and lactation. 11th end. Philadelphia, PA: Lippincott Williams \& Wilkins, 2017.

- Lactmed (US National Library of Medicine), https://toxnet.nlm.nih.gov/ newtoxnet/lactmed.htm

- Motherisk, The Hospital for Sick Children, Toronto, Canada, www.motherisk.org
- Organisation of Teratology Information Specialists (MothertoBaby), www.mothertobaby.org

- Reprotox (can be accessed by NSW Health employees through CIAP), https://reprotox.org

- The Royal Hospital for Women MotherSafe, www.mothersafe.org.au

- The Royal Women's Hospital Pregnancy and Breastfeeding Guide, https://the womenspbmg.org.au
- UK Teratology Information Services - BUMPS (best use of medicines in pregnancy), http://www.medicinesinpregnancy.org

- Pregnancy drug information centres

- ACT: The Canberra Hospital, (02) 62443333

- NSW: MotherSafe, The Royal Hospital for Women, (02) 9283 6539; Toll free (NSW only) 1800647848 
Table 1. Examples of differing pregnancy advice between evidence-based resources and product information citing commonly queried medications received at MotherSafe (cont'd)

\begin{tabular}{|c|c|c|c|}
\hline Metronidazole & $\begin{array}{l}\text { - Safe to use } \\
\text { - Take in divided doses } \\
\text { if possible }\end{array}$ & $\begin{array}{l}\text { Metronidazole use during } \\
\text { pregnancy has not been shown } \\
\text { to increase the risk of adverse } \\
\text { pregnancy outcome }\end{array}$ & $\begin{array}{l}\text { - Use in pregnancy must be carefully } \\
\text { evaluated } \\
\text { - Crosses the placenta and enters } \\
\text { fetal circulation rapidly } \\
\text { - Effects on human fetal } \\
\text { organogenesis are not known } \\
\text { - Should not be used in the first } \\
\text { trimester of pregnancy } \\
\text { - Not been shown to be teratogenic in } \\
\text { either human or animal studies, such } \\
\text { a possibility cannot be excluded } \\
\text { - Use for the treatment of } \\
\text { trichomoniasis in the second and } \\
\text { third trimesters should be restricted } \\
\text { to those in whom local palliative } \\
\text { treatment has been inadequate to } \\
\text { control symptoms }\end{array}$ \\
\hline
\end{tabular}

\begin{tabular}{lll}
\hline $\begin{array}{l}\text { Asthma } \\
\text { preparations }\end{array}$ & - Limited experience & Provides information from \\
including & but asthma control is & Therapeutic Guidelines that \\
budesonide/ & paramount & $\begin{array}{l}\text { uncontrolled asthma is a } \\
\text { greater risk to the baby than }\end{array}$ \\
formoterol & & $\begin{array}{l}\text { use of asthma medications } \\
\text { (Symbicort) }\end{array}$
\end{tabular}

Consumer Medicines Information

- Patients advised to tell their doctor immediately if they become pregnant
- Budesonide/formoterol inhaler should be used during pregnancy only if the potential benefit justifies the potential risk to the fetus

- Only after special consideration should budesonide/formoterol inhaler be used during the first three months and shortly before delivery
- Patients advised to tel their doctor if they are pregnant, or intend to become pregnant, or breastfeeding

- Doctor will discuss possible risks and benefits of using budesonide/ formoterol inhaler during pregnancy and while breastfeeding

- Patients advised to tell their doctor if they are pregnant or intend to become pregnant

large numbe and women of childbearing age

- No increase in the frequency of malformations or other direct or indirect harmful effects on the fetus

- Erythromycin should be used during pregnancy only if clearly needed

- Safety of clarithromycin in pregnancy has not been established

- Use in pregnancy is not advised without carefully weighing the benefits against the risk

- Patients who become pregnant while taking clarithromycin should advised of the potential hazard to the fetus
- Doctor will discuss the risks and benefits involved pyloric stenosis confirmed in other samples

- Erythromycin estolate is avoided because of potential maternal hepatotoxicity

- Clarithromycin produced adverse pregnancy outcome in experimental animals at low-
order multiples of the human dose level on a $\mathrm{mg} / \mathrm{kg}$ basis.

- Not possible to conclude that clarithromycin therapy increases the risk of abnormal human development; however, alternative antibiotics are recommended during pregnancy

Beta-lactam $\quad \cdot$ Safe to use
penicillins
including
flucloxacillin

- Use of penicillins during pregnancy is generally considered to be safe, unless patients are allergic

- Penicillins are frequently the drugs of choice for susceptible organisms commonly encountered in pregnancy

- Flucloxacillin has not been shown to have teratogenic effects in animal studies

- Flucloxacillin has been in clinical use since 1970

- No evidence of untoward effects in the limited number patients reported to have used flucloxacillin while pregnant

- Use of flucloxacillin in pregnancy should be reserved for cases considered essential by the clinician
- Patients advised not to take flucloxacillin if they are pregnant or intend to become pregnant, unless they have discussed the risks and benefits with their doctor 


\begin{tabular}{|c|c|c|c|c|}
\hline Drug & $\begin{array}{l}\text { Australian Medicines } \\
\text { Handbook }\end{array}$ & LACTMED & $\begin{array}{l}\text { Monthly Index of Medical } \\
\text { Specialties }\end{array}$ & $\begin{array}{l}\text { Consumer Medicines } \\
\text { Information }\end{array}$ \\
\hline Sertraline & $\begin{array}{l}\text { - Considered safe to } \\
\text { use and preferred } \\
\text { antidepressant } \\
\text { in breastfeeding } \\
\text { women } \\
\text { - Low levels in } \\
\text { breast milk } \\
\text { - Adverse effects } \\
\text { (eg drowsiness, } \\
\text { irritability) occur } \\
\text { occasionally in } \\
\text { breastfed babies }\end{array}$ & $\begin{array}{l}\text { - Low levels of sertraline in breast milk } \\
\text { - Small amounts ingested by the infant are } \\
\text { not usually detectable the serum } \\
\text { - Weakly active metabolite norsertraline } \\
\text { (desmethylsertraline) is often detectable in } \\
\text { low levels in infant serum } \\
\text { - Accumulation and symptoms similar to neonatal } \\
\text { abstinence in preterm infants with impaired } \\
\text { metabolic activity is possible but rare } \\
\text { - Regarded by authoritative reviewers preferred } \\
\text { antidepressants during breastfeeding } \\
\text { - Mothers taking a selective serotonin reuptake } \\
\text { inhibitor (SSRI) during pregnancy and postpartum } \\
\text { may have more difficulty breastfeeding and may } \\
\text { need additional breastfeeding support } \\
\text { - Following exposure to an SSRI in the third } \\
\text { trimester, breastfed infants have a lower risk of } \\
\text { poor neonatal adaptation than formula-fed infants }\end{array}$ & $\begin{array}{l}\text { Excreted in milk } \\
\text { - Limited data on sertraline } \\
\text { levels in breast milk } \\
\text { - Reports of adverse effects } \\
\text { in breastfed infants whose } \\
\text { mothers were taking } \\
\text { sertraline } \\
\text { - Use while breastfeeding is } \\
\text { not recommended } \\
\text { - If used during lactation, the } \\
\text { physician should be aware } \\
\text { that withdrawal reactions } \\
\text { have been reported in } \\
\text { some neonates whose } \\
\text { mothers had been on SSRI } \\
\text { antidepressants, including } \\
\text { sertraline }\end{array}$ & $\begin{array}{l}\text { Patients are advised to } \\
\text { tell their doctor if they } \\
\text { are breastfeeding or } \\
\text { intending to breastfeed } \\
\text { - Sertraline is excreted } \\
\text { into breast milk and } \\
\text { may affect the baby } \\
\text { - The doctor should } \\
\text { discuss the risks } \\
\text { and benefits of } \\
\text { taking sertraline } \\
\text { when pregnant or } \\
\text { breastfeeding }\end{array}$ \\
\hline Aciclovir & - Safe to use & $\begin{array}{l}\text { - At the highest maternal doses, } 1 \% \text { of the infant } \\
\text { dose is present in breast milk } \\
\text { - Not be expected to cause any adverse effects } \\
\text { in breastfed infants } \\
\text { - Topical acyclovir applied to small areas of the } \\
\text { mother's body, away from the breast, should } \\
\text { pose no risk to the infant } \\
\text { - Use water-miscible cream or gel } \\
\text { - Use of ointments may expose the infant to } \\
\text { high levels of mineral paraffins via licking }\end{array}$ & $\begin{array}{l}\text { - Limited human data show } \\
\text { that aciclovir does pass into } \\
\text { breast milk } \\
\text { - Caution is therefore } \\
\text { advised if aciclovir is to } \\
\text { be administered to a } \\
\text { nursing woman } \\
\text { - Use while breastfeeding } \\
\text { only if the benefits to } \\
\text { the mother outweigh the } \\
\text { potential risks to the baby }\end{array}$ & $\begin{array}{l}\text { Patients are advised to } \\
\text { tell their doctor if they } \\
\text { are breastfeeding or } \\
\text { intending to breastfeed }\end{array}$ \\
\hline $\begin{array}{l}\text { Budesonide/ } \\
\text { formoterol }\end{array}$ & $\begin{array}{l}\text { - Considered safe } \\
\text { to use }\end{array}$ & $\begin{array}{l}\text { - No published data are available on the use } \\
\text { of inhaled formoterol during lactation } \\
\text { - Data on terbutaline, a related drug, indicate } \\
\text { very low levels are present in breast milk }{ }^{1} \\
\text { - Generally agrees that use of inhaled } \\
\text { bronchodilators is acceptable during } \\
\text { breastfeeding because of the low } \\
\text { bioavailability and maternal serum levels } \\
\text { after use }\end{array}$ & $\begin{array}{l}\text { Use while breastfeeding only } \\
\text { when the expected benefit } \\
\text { to the mother is greater than } \\
\text { any possible risk to the child }\end{array}$ & $\begin{array}{l}\text { Patients are advised } \\
\text { to tell their doctor } \\
\text { if they are pregnant } \\
\text { or breastfeeding or } \\
\text { intending to become } \\
\text { pregnant } \\
\text { - The doctor should } \\
\text { discuss the possible } \\
\text { risks and benefits of use } \\
\text { during pregnancy and } \\
\text { while breastfeeding }\end{array}$ \\
\hline Metronidazole & $\begin{array}{l}\text { - Safe to use } \\
\text { - May cause some } \\
\text { bitterness in milk } \\
\text { - Use in divided doses } \\
\text { after breastfeeding } \\
\text { rather than single } \\
\text { daily doses }\end{array}$ & $\begin{array}{l}\text { - Following intravenous and oral therapy, levels } \\
\text { in breast milk are lower that the infant doses } \\
\text { - Presence of active metabolite may increase } \\
\text { total infant exposure } \\
\text { - Plasma levels of the drug and metabolite are } \\
\text { measurable, but less than maternal plasma levels } \\
\text { - Case reports of candidiasis and diarrhoea have } \\
\text { been reported } \\
\text { - Comparative trial suggeststhat oral and } \\
\text { rectal colonisation with Candida albicans } \\
\text { might be more common in infants exposed } \\
\text { to metronidazole }\end{array}$ & $\begin{array}{l}\text { - Secreted in breast milk } \\
\text { - Breastfeeding is not } \\
\text { recommended because } \\
\text { of tumorigenic and } \\
\text { mutagenic potential }\end{array}$ & $\begin{array}{l}\text { Patients are advised to } \\
\text { tell their doctor if they } \\
\text { are breastfeeding }\end{array}$ \\
\hline
\end{tabular}

- Qld: Queensland Medicines Advice \& Information Service, 0736367098

- SA: South Australia Obstetric and Paediatric Medicines Information Service, Women's and Children's Hospital, 0881617222

- Vic: Monash Medicines Information, 0395942361

- Royal Women's Hospital, 0383453190
- WA: Western Australia Obstetric Medicines Information Service, King Edward Memorial Hospital, 0864582723

\section{Author}

Majella Hill MSc, BPharm, Pharmacist Counsellor MotherSafe, Royal Hospital for Women, Randwick, NSW.Majella.Hill@health.nsw.gov.au

Competing interests: None.

Funding: None.
Provenance and peer review: Not commissioned, externally peer reviewed.

\section{References}

1. Therapeutic Guidelines. Depression in pregnancy and the postpartum. West Melbourne, Vic: Therapeutic Guidelines, date unknown.

2. Buckley N, Rossi S. Important changes to Australian Medicines Handbook (AMH) content in 2016. Available at www.amh.net.au/resources/ public/amh_notice_pregnancy_categories_2016.pdf [Accessed 19 October 2018]. 
Table 2. Examples of differing advice regarding drug use while breastfeeding (cont'd)

\begin{tabular}{|c|c|c|c|c|}
\hline Drug & $\begin{array}{l}\text { Australian Medicines } \\
\text { Handbook }\end{array}$ & LACTMED & $\begin{array}{l}\text { Monthly Index of Medical } \\
\text { Specialties }\end{array}$ & $\begin{array}{l}\text { Consumer Medicines } \\
\text { Information }\end{array}$ \\
\hline Macrolides & $\begin{array}{l}\text { - Safe to use } \\
\text { - May cause } \\
\text { loose bowel } \\
\text { actions in infant }\end{array}$ & $\begin{array}{l}\text { - Erythromycin and clarithromycin are safe for } \\
\text { use in infant } \\
\text { - Low levels of erythromycin and clarithromycin } \\
\text { in breast milk } \\
\text { - Safe to use while breastfeeding } \\
\text { - Small amounts in milk are unlikely to cause } \\
\text { adverse effects in the infant } \\
\text { - Monitor the infant for irritability and possible } \\
\text { effects on the gastrointestinal flora, such } \\
\text { as diarrhoea, candidiasis (thrush, diaper } \\
\text { rash). One case report and unconfirmed } \\
\text { epidemiologic evidence indicate that the risk } \\
\text { of hypertrophic pyloric stenosis in infants } \\
\text { might be increased by maternal use of } \\
\text { erythromycin during breastfeeding }\end{array}$ & $\begin{array}{l}\text { - Erythromycin is secreted } \\
\text { in breast milk in low } \\
\text { concentrations } \\
\text { - Clarithromycin and other } \\
\text { macrolides are excreted into } \\
\text { breast milk } \\
\text { - Safety of clarithromycin } \\
\text { during breastfeeding has } \\
\text { not been established }\end{array}$ & $\begin{array}{l}\text { Patients are advised to } \\
\text { tell their doctor if they } \\
\text { are breastfeeding } \\
\text { The doctor should } \\
\text { discuss the possible } \\
\text { risks and benefits }\end{array}$ \\
\hline Flucloxacillin & $\begin{array}{l}\text { - Safe to use } \\
\text { - May cause loose } \\
\text { bowel actions in } \\
\text { infant }\end{array}$ & $\begin{array}{l}\text { Flucloxacillin is not approved by the US Food } \\
\text { and Drug Administration } \\
\text { - Acceptable to use during breastfeeding and } \\
\text { is frequently used abroad to treat mastitis in } \\
\text { nursing mothers }{ }^{1-3} \\
\text { - Limited information indicates that flucloxacillin } \\
\text { levels in milk are low } \\
\text { - Not expected to cause adverse effects in } \\
\text { breastfed infants } \\
\text { - May cause some disruption of the infant's } \\
\text { gastrointestinal flora, resulting in diarrhoea } \\
\text { or thrush, have been reported with } \\
\text { penicillins, but these effects have not been } \\
\text { adequately evaluated }\end{array}$ & $\begin{array}{l}\text { - Excreted in breast milk in } \\
\text { trace amounts } \\
\text { - Alternative feeding } \\
\text { method is recommended } \\
\text { to avoid any possible } \\
\text { sensitisation of the } \\
\text { newborn }\end{array}$ & $\begin{array}{l}\text { Patients are advised } \\
\text { not to use flucloxacillin } \\
\text { if breastfeeding or } \\
\text { intending to breastfeed }\end{array}$ \\
\hline Levonorgestrel & - Safe to use & $\begin{array}{l}\text { Breastfeeding can be resumed } 3-4 \text { hours after } \\
\text { each dose of levonorgestrel used as a postcoital } \\
\text { contraceptive. } \\
\text { - No long-term adverse effects on } \\
\text { breastfeeding when used as postcoital } \\
\text { contraceptive }\end{array}$ & $\begin{array}{l}\text { - Progestogens do not appear } \\
\text { to affect the quantity or } \\
\text { quality of breast milk } \\
\text { - Levonorgestrel has been } \\
\text { identified in the breast milk } \\
\text { following oral administration } \\
\text { - Patients are advised not } \\
\text { to breastfeed within three } \\
\text { days after use }\end{array}$ & $\begin{array}{l}\text { Patients are advised } \\
\text { not to breastfeed within } \\
\text { three days after use }\end{array}$ \\
\hline Ulipristal & $\begin{array}{l}\text { - Excreted into } \\
\text { breast milk } \\
\text { - No other } \\
\text { clinical data } \\
\text { - Manufacturer } \\
\text { recommends } \\
\text { avoiding } \\
\text { breastfeeding for } \\
\text { seven days after } \\
\text { taking ulipristal }\end{array}$ & $\begin{array}{l}\text { Emergency postcoital contraceptive } \\
\text { - No information available on the clinical } \\
\text { use of ulipristal during breastfeeding } \\
\text { - Manufacturer recommends avoiding use } \\
\text { of ulipristal acetate during breastfeeding } \\
\text { - Others recommend withholding } \\
\text { breastfeeding for } 24 \text { hours after use, as } \\
\text { levels are low in breast milk because of } \\
\text { extensive protein binding ( }>98 \%) \text { and } \\
\text { relative infant dose of } 0.8 \% 7\end{array}$ & $\begin{array}{l}\text { - Excreted in breast milk } \\
\text { - Effect on newborn/infants } \\
\text { has not been studied } \\
\text { - Risk to the breastfed } \\
\text { child cannot be excluded } \\
\text { - Breastfeeding is not } \\
\text { recommended for one } \\
\text { week after use } \\
\text { - During this time patients } \\
\text { are advised to express the } \\
\text { breast milk to stimulate } \\
\text { lactation, but discard } \\
\text { the milk }\end{array}$ & $\begin{array}{l}\text { Effects on breastfed } \\
\text { babies in the week after } \\
\text { taking ulipristal are not } \\
\text { known } \\
\text { - Patients are advised } \\
\text { to not breastfeed for } \\
\text { one week after use } \\
\text { - While using ulipristal } \\
\text { and for one week } \\
\text { after use, patients } \\
\text { should use a breast } \\
\text { pump to maintain } \\
\text { milk production but } \\
\text { discard the milk }\end{array}$ \\
\hline
\end{tabular}

3. Kennedy D. Classifying drugs in pregnancy. Aust Presc 2014;37:112-14. doi: 10.18773/ austprescr.2014.018.

4. Hill M. The MotherSafe experience: Demystifying perceptions regarding treating pregnant or breastfeeding mothers. J Pharm Pract 2015;45:72-75. doi: https://doi.org/10.1002/ jppr.1076.

5. Therapeutic Goods Administration. Prescribing medicines in pregnancy database. Symonston, ACT: TGA, 2018. Available at www.tga.gov.au/ prescribing-medicines-pregnancy-database [Accessed 30 August 2018].
6. US Food \& Drug Administration. Pregnancy and Lactation Labeling (Drugs) Final Rule. Silver Spring, MD: FDA, 2014 Available at www.fda. gov/Drugs/DevelopmentApprovalProcess/ DevelopmentResources/Labeling/ucm093307. htm [Accessed 30 August 2018].

7. Hale TW. Medications and mothers' milk online. New York: Springer Publishing Company, 2018. Available at www.medsmilk.com [Accessed 1 April 2018].

8. Australian Health Practitioner Regulation Agency. AHPRA annual report 2016/17: Performance summary. Melbourne: AHPRA, 2017. correspondence ajgp@racgp.org.au 